\title{
How public libraries in Meru County, Kenya, address the business information needs of small-scale enterprises
}

Information Development

2017, Vol. 33(4) 4I8-435

(C) The Author(s) 2016

Reprints and permission:

sagepub.co.uk/journalsPermissions.nav

DOI: $10.1177 / 0266666916667998$

journals.sagepub.com/home/idv

(A)AGE

\author{
Paul M. Gichohi \\ Kenya Methodist University

\section{Omwoyo B. Onyancha} \\ University of South Africa
}

Frankwell W. Dulle

Sokoine University of Agriculture, Tanzania

\begin{abstract}
The purpose of the study was to explore how public libraries in Meru County, Kenya, address the information needs of small-scale business enterprises (SBEs) in the region. It was carried out from 2013 to 20I5. A quantitative approach and survey research design were adopted to collect data from SBE traders and staff from three public libraries in Meru County. The study found that the business information needs of SBEs are myriad, sectorspecific and cut across all stages of business development. These needs are fulfilled by consulting informal information resources and places. The few SBEs traders who were using public libraries for business information expressed high levels of satisfaction. The study concludes that public libraries have facilitative and functional roles of providing business information to SBEs by collaborating with like-minded stakeholders. The study recommends symmetrical dissemination of business information and the re-positioning of public libraries as community development centers by providing value-based and sector-specific business information solutions.
\end{abstract}

\section{Keywords}

business information, small business enterprises, business information needs, public libraries, Kenya

Submitted: 15 April, 2016; Accepted: 15 August, 2016.

\section{Providing business information from public libraries to small business is a fairly new concept in Kenya.}

\section{Introduction and conceptual setting}

Small-scale business enterprises (SBEs) are the key focus in this study. The meaning and what constitutes SBEs depends on the context and differs from one country to another. The definition is largely in terms of their capital base, market share, number of employees, shareholding, cash flow, turnover volume, net worth value and management structures (Bridge O'Neill and Cromie, 2003; Coy, Shipley, Omer and Khan 2007). The definition by Bridge, O'Neill and Cromie (2003:182) was specifically preferred in this study due to its description of SBEs as independently, solely owned and managed commercial ventures that are not dominant in their competitive area, employ less than 10 employees, have low sales turnover, low balance sheet value, and have no formal management structure.

Chiware (2008), Migiro (2005), Bridge, O’Neill and Cromie (2003) and Saleemi (2009) have provided key characteristics of SBEs that include: survivaloriented, widely distributed and dispersed, flexible

\section{Corresponding author:}

Paul M. Gichohi, Library Department, Kenya Methodist University, Kenya, PO Box 267-60200, Meru, Kenya.

Email: pmakuster@gmail.com 
and adaptable, labor intensive, suffer from scanty business information, have limited access to resources while business financing is mostly supplied by one person, have weak financial discipline, majority do not file tax returns, most use semi-skilled workers, majority are sole proprietorship businesses, have poor book keeping practices, and conduct little or no market research.

Notwithstanding these characteristics, SBEs are generally regarded as pillars of a nation's economy. They have been linked directly to economic development in both developed and developing countries (Alasadi and Abdelrahim, 2007). They create employment, alleviate poverty, generate wealth, contribute to the Gross Domestic Product (GDP), pave the way for innovations and enhance the supply chain of products, and help to ensure distribution of economic power to the low income class. They are also instrumental in curtailing rural-urban migration, since SBEs are prevalent in remote rural areas (Bridge, O'Neill and Cromie, 2003:181-184). In Kenya, the Micro and Small Enterprises (MSE) sector plays a significant role in the growth of the economy (Kenya National Bureau of Statistics, 2014:38). It employs a large number of people and contributes to the national income (Government of Kenya, 2007).

Despite the capacity of SBEs contributing $80 \%$ of employment in Kenya (African Economic Outlook, 2011:2), their contribution towards Gross Domestic Product (GDP) has been about 20\%, which indicates dismal performance (Ong'olo and Awino, 2013:8). This may be attributed to several challenges that include: lack of markets, technology, infrastructure, institutional support, stiff competition and business information asymmetry. The business information asymmetry leaves SBEs with numerous unfulfilled information needs; this study set out to explore how they can be addressed by public libraries.

\section{Business information needs of SBEs}

The scope of business information need cuts across all facets of business development activities such as start-up information, financing, operations, production, growth, marketing, insurance and international business among others (Vuori, 2006).

Different sectors in the business world exhibit different business information needs, which are determined by the types of business activities, the size of businesses, the stage of growth and the education level of business owners (Jaworski, 2012:13). These business information needs are both financial and non-financial needs which, according to Feldmann (2014), are required by the business community. Numerous studies, such as those by Garcia-Alsina, Ortoll and Cobarsí-Morales (2011), Kamunge, Njeru and Tirimba (2014), and Karadag (2015) have focused on financial information in business enterprises across different economies. These studies underpin the critical role of financial information in business development.

The implications of non-financial information needs in business development have also been studied by, for example, Coy, Shipley, Omer, Khan (2007), Olabisi, Olagbemi and Atere (2011), Mbugua, Wangoi, Ogada and Kariuki (2013), Erastus, Stephen and Abdullai (2014) and Kamunge, Njeru and Tirimba (2014). Most of these studies have examined non-financial information needs under factors that promote growth of micro, small and medium enterprises. Examples of such needs include: training on business matters, information on infrastructure development, information on available institutional support and networks, information on trade policies and legal framework.

The study by Anwar and Tuqan (2006:341) interviewed senior officials from 20 business firms to establish information needs and use in the construction industry in Kuwait, which were found to be: finance, marketing, production, legal, staffing, management, administration and new product developments. The study by Vuori (2006) underpinned the essence of business intelligence information to the business community, citing examples such as Germany, America, Finland and Netherlands where business intelligence information is highly regarded as critical information need for survival of businesses. The business information needs identified by the above researchers are more inclined to large business enterprises. Urwin (2000:131) held that SBEs need more established flows of information than large enterprises because they are less structured, have limited fiscal resources and cannot afford hiring information specialists as compared to their counterparts.

Studies by Okello-Obura, Minishi-Majanja, Cloete and Ikoja-Odongo (2007), Smith (2009), Kassim (2010), Feldmann (2014), Kadli and Kumbar (2011) have attempted to describe the specific information needs of small business traders. The study by Kassim (2010:57-69) was the more significant to this study since it identifies elaborate business information needs for people contemplating to start a business. It 
specifically investigated the information needs of 400 Malaysian Bumiputera (indigenous Malay) government staff who were about to retire and were assumed to be intending to venture into business upon retirement.

From the aforementioned studies, it is clear that the business information needs for SBEs vary with industries and economies. They were important in providing the variables of investigation in this study. The reviewed studies did not, however, provide the appropriate measures needed to address the identified business information needs. This study postulates that public libraries play - or should play - a critical role in addressing the business information needs of SBEs.

\section{Public libraries}

Public libraries are traditionally known as performing four main functions: informative, educational, recreational and cultural (Andrade and Magalhães, 1979, in Santos, 2009). However, in 1994, the UNESCO Manifesto on Public Libraries highlighted the expanded mission of public libraries in providing information services adapted to the local businesses community (Santos, 2009). Public libraries nowadays contribute immensely to the nation's literacy development, lifelong learning, socio-economic development, democracy and citizenship (Mutshewa, 2009:18-23). Cannon (1999) describes public libraries as the main information resource centers for rural communities. According to Santos, the origin of public libraries providing information services to business people is based on the Community Information Service (CIS) with examples from both Great Britain and the United States in the 19th century. Santos drew more recent examples from Australia, Netherlands and Canada, where the dissemination of information to the business community is now a common task of public libraries (Santos, 2009:85).

Despite the changing roles of the public library described above, many public libraries in the developing countries are yet to fully embrace the provision of socio-economic information (Mutshewa, 2009). Mutshewa proposed a framework for improving the provision of business information services in Botswana public libraries, while Fairbairn (2012:2) described how public libraries are expected to act like local hubs for community development.

Since the inception of public libraries in Kenya in April 1965 through the Kenya National Library Service (KNLS), they have continued to expand regionally with presence in almost every county. Notably, growing community information needs, for example, the demand for health, career, agriculture and business information, have continued to amass pressure on public libraries in Kenya to widen their array of services. However, a study by Electronic Information for Libraries (2012) reported that public libraries in Kenya are mainly supporting the education system, hence this study noted the great need to find out how they can enrich and expand their information services to other organized community groups such as the SBEs.

\section{Meru County}

Meru County is in the upper eastern region of Kenya. The county has a total area of 6,936 square kilometers. It had a population of $1,356,301$ million by the 2009 census (latest available census data), which was widely distributed among nine sub-counties (Ministry of Devolution and Planning, 2013:13; Meru County Government, 2014a).

Meru County has high agricultural potential, ascribed to the many small agribusiness ventures. Information from Meru County business licencing office showed that there were 4,514 registered SBEs by August 2015. The majority of these SBEs are solely owned; only a few are jointly owned. The main agribusiness activities revolve around agricultural products such as miraa (khat), bananas, wheat, green vegetables, potatoes, cereals, coffee, tea, French beans, dairy products such as milk, and other consumables. The tourism industry is well grounded in this county with Meru National Park, Mount Kenya, and the Lewa Downs Ranch - a major tourist center which is privately owned. The county has several factories and processing units such as Mount Kenya milk processing unit, tea and coffee processing zones, bread and animal feed factories. The main household income is from three main areas: the agricultural sector, which represents $80 \%$, wage earners $(10 \%)$ and other self-employed (10\%) (Meru County Government, 2014b).

According to the Ministry of Devolution and Planning (2013), the unemployment rate in Meru County is high, at approximately $65 \%$ of the total labor force. It also has the highest level of poverty among the top five richest counties in Kenya. However, the opportunities to engage in business activities are curtailed by low investment in job creation ventures, lack of financial resources and lack of 
Table I. Description of public libraries in Meru County.

\begin{tabular}{|c|c|c|c|}
\hline Features & Meru District Library & Mikumbune Community Library & Timau Community Library \\
\hline Year of Inception & $\begin{array}{l}\text { Established in } 1985 \text { as } \\
\text { directed by Kenya } \\
\text { National Library } \\
\text { Service Board }\end{array}$ & $\begin{array}{l}\text { Was started in } 2003 \text { under the } \\
\text { partnership of Kenya National } \\
\text { Library Service Board and the } \\
\text { Mikumbune community }\end{array}$ & $\begin{array}{l}\text { Was opened in } 2009 \text { under the } \\
\text { partnership of Kenya National } \\
\text { Library Service Board and the } \\
\text { Timau community }\end{array}$ \\
\hline Vision & $\begin{array}{l}\text { The hub of information } \\
\text { and knowledge for } \\
\text { empowerment }\end{array}$ & $\begin{array}{l}\text { A national centre of excellence that } \\
\text { preserves and disseminates } \\
\text { information for knowledge and } \\
\text { creativity }\end{array}$ & $\begin{array}{l}\text { A centre of excellence that } \\
\text { preserves and disseminates } \\
\text { information for knowledge and } \\
\text { creativity }\end{array}$ \\
\hline \multirow[t]{4}{*}{ Staffing } & Seven technical staff & Three technical staff & Three technical staff \\
\hline & Two support staff & Two support staff & Three support staff \\
\hline & Two security staff & Two security staff & One security staff \\
\hline & Total is II & Total is 7 & Total is 7 \\
\hline \multirow[t]{2}{*}{ Collection } & I5,000 volumes books & 8,705 volumes books & 7,380 volumes books \\
\hline & $\begin{array}{l}\text { 2,100 audio-visual } \\
\text { materials }\end{array}$ & I,659 audio-visual materials & I,37I audio-visual materials \\
\hline \multirow{2}{*}{$\begin{array}{l}\text { Registered users } \\
\text { as at November } \\
2015\end{array}$} & I,210 Adults & I,734 Adults & I,707 Adults \\
\hline & I,868 Children & 2,239 Children & 2,27I Children \\
\hline \multirow[t]{3}{*}{ Operating hours } & Monday to Friday: & Monday to Friday: $8.00 \mathrm{am}-6.30 \mathrm{pm}$ & Monday to Friday: $8.00 \mathrm{am}-6.30 \mathrm{pm}$ \\
\hline & 8.00am-6.30 pm & Saturday: $8.30 \mathrm{am}-5.00$ pm & Saturday: $8.30 \mathrm{am}-5.00 \mathrm{pm}$ \\
\hline & $\begin{array}{l}\text { Saturday: } 8.30 \mathrm{am}-5.00 \text { pm } \\
\text { Closed on Sunday and all } \\
\text { gazetted public holidays. }\end{array}$ & $\begin{array}{l}\text { Closed on Sunday and all gazetted } \\
\text { public holidays. }\end{array}$ & $\begin{array}{l}\text { Closed on Sunday and all gazetted } \\
\text { public holidays. }\end{array}$ \\
\hline
\end{tabular}

business information (Meru County Government, 2014a). Information from Meru County's website (http://meru.go.ke/; Meru County Government, 2014 b) indicated that the county endeavours to strengthen institutional support for the flow of information to the society and other stakeholders for socio-economic development.

Meru County has six universities (public and private), and seven middle level colleges/training institutes, all of which offer business administration courses where entrepreneurship training is offered as a course unit or as an area of specialization. The county had only three public libraries as at August 2015, namely, Meru District Library, Mikumbune Community Library and Timau Community Library. The description of these libraries is provided in Table 1. Meru is one of only three counties (the others are Nyeri and Wajir) that have as many as three public libraries; some other counties have none. In Kenya, all public libraries are centrally administered by the Kenya National Library Service (KNLS), which is one of the state corporations. The main governing body of KNLS is a national board. The board is charged with the responsibility of developing, promoting, establishing and equipping all public libraries in Kenya. The State Corporations Act, Cap 446 of the laws of Kenya, provides detailed guidelines on the operations of the board. Each public library, however, has a head who is responsible for day-to-day operations.

As a state-owned organization, public libraries are currently being funded by the national government. The acquisition of collections is centrally done from KNLS head office in Nairobi, after which the fully processed information materials are sent to the branch libraries. The branch libraries are expected to submit requests for book purchases and other necessities once a year.

Although Meru County's profile looks impressive and promising, its strategic intent lacks candid measures for improving access to business information. The information on the Meru County official website at the time of developing the research proposal for this study was very scanty. However, the county has opportunities to address the high rate of unemployment by educating and furnishing people with appropriate business information that would ultimately interest them to self-employment. The mechanisms of providing business information are therefore critical in supporting the development of 
SBEs. The three public libraries in Meru County are expected to partner with other stakeholders in executing this mandate.

\section{Problem statement and purpose of the study}

Although SBEs have made an immense contribution to national and regional economic growth in Kenya, their development is hampered by the lack of proper mechanisms to address their business information needs. The SBEs sector in Meru County depends on inefficient, unsystematic and fragmented mechanisms of providing solutions to their business information needs. Although public libraries in Botswana, for example, are regarded as information resource centers for community development, (Mutshewa 2009) their role in meeting the information needs of SBEs in Kenya has not been clearly demarcated. This study was motivated by the need to provide empirical demarcation by exploring how public libraries in Kenya can provide solutions to information needs of SBEs.

The study explored the extent to which public libraries address the information needs of SBEs in Meru County by:

- identifying their information needs

- ascertaining the levels of SBEs' awareness of providers of business information

- gauging the usage and satisfaction level of the providers of business information

- determining the numbers and types of business information queries received at public libraries from SBEs

- analyzing the purposes and/or reasons for SBEs' visits to the public libraries

- identifying measures needed at public libraries in order to support the development of SBEs in Meru County, and

- providing suggestions that can improve the public libraries' information service delivery to SBEs.

\section{Research methodology}

This study reports on part of the findings from a broad $\mathrm{PhD}$ study on the role of public libraries in the development of SBEs in Meru County, Kenya which took place from 2013 to 2015 . The study used the positivism paradigm to explore the identified phenomena. It focused on the quantitative investigation of the extent to which public libraries in Meru County, Kenya address the information needs of SBEs in the region. Survey research design was adopted, wherein a total of 355 SBEs traders and 21 staff members from three public libraries in Meru County constituted the target population.

There were 4,514 registered SBEs in Meru County by August 2015, distributed in the main town centres, that is, Makutano $(1,217)$, Maua $(1,156)$, Nkubu (1,250), Kianjai (468) and Timau (423). The formula by Hoyle, Harris and Judd (2002) provided below was used to determine the sample size of SBEs traders:

$$
\mathrm{n}=\frac{\mathrm{N}}{1+\left[\begin{array}{l}
\mathrm{N}(\mathrm{L} / 100) 2 \\
1.962 \mathrm{p}(1-\mathrm{p})
\end{array}\right]}
$$

Where $\mathrm{N}=$ total number of SBEs i.e. (4514)

1. $\mathrm{n}=$ the required sample size

2. $\mathrm{L}=$ maximum allowed error (in this case, $5 \%$ )

3. $\mathrm{P}=$ Expected proportion of SBEs that may seek for business information in Meru County (in this case, 0.5)

The formula therefore led to the following actual calculations:

$$
\mathrm{n}=\frac{4514}{1+\left[\begin{array}{l}
4514(5 / 100) 2 \\
1.962(0.5)(0.5)
\end{array}\right]}=355
$$

In order to get the sample size of each cluster centre, further calculations were done as follows:

1. Nkubu $\mathrm{n}=(1217 / 4514) * 355=96$ SBEs

2. Maua/Kangeta $\mathrm{n}=(1156 / 4514) * 355=91$ SBEs

3. Meru/Makutano $\mathrm{n}=(1250 / 4514) * 355=$ 98 SBEs

4. Kianjai $\mathrm{n}=(468 / 4514) * 355=37$ SBEs

5. Timau $\mathrm{n}=(423 / 4514) * 355=33$ SBEs

All 21 staff working in the three public libraries were included in the study since they were few in number. Cluster sampling was used to sample the SBE traders due to its suitability for a widely dispersed large population, being economical, and due to the ease of explaining and training research assistants (Mugenda, 2008:193; Cooper and Schindler, 2008:389; Saunders, Lewis and Thornhill, 2009:228). The initial clusters of this study were purposively / judgmentally considered from the nine sub-counties, 
after which systematic sampling was used to get the individual SBEs units/owners, as demonstrated above.

Well-structured questionnaires were used to collect the required data. Three research assistants were trained and engaged to assist in administering the questionnaires. The field work was sponsored by the researcher and took place October - December 2015. Descriptive statistics were used in the analysis with the help of SPSS version 20 and Microsoft Excel 2013. All open-ended questions were analyzed thematically.

\section{Results}

\section{Response rate and background information} of respondents

The response to this study was 296 SBE traders $(83.4 \%)$ and 20 staff from the three public libraries (95\%). Table 2 reveals that the owners of SBEs (herein sometimes simply called 'SBEs' to refer to both the enterprises and their owners) in Meru County have basic education, with most of them having a Form 4 or Form 6 secondary school certificate, a college certificate and/or a college diploma. This indicates that most SBEs possess the basic numeracy and literacy skills that are necessary in understanding business information. Further results show that approximately half of SBEs in Meru County have no employees. Most are sole proprietorships, require less capital and earn moderate income. This may explain why 195 (65.9\%) of the SBEs had no background training in business matters. This points out the opportunity to empower SBEs with the requisite business skills. It also exposes the magnitude of the training gaps which the enterprise development unit of Meru County needs to address.

The competence of staff in terms of qualifications and experience is critical in the provision of information by public libraries. The majority of public library staff were technically qualified and had experience, as shown in Table 3. Half of 20 staff respondents $(50 \%)$ had a college diploma, while $25 \%$ had certificates in library studies. The majority of the staff (17: $85 \%$ ) had 3 or more years of work experience. The biggest group of staff (8: $40.0 \%$ ), were in assistant librarian positions followed by 4 $(20.0 \%)$ in library assistant positions.

\section{Information needs of the SBEs}

SBEs were asked to first identify the information needs that applied to their business and secondly, to indicate the level of significance of the various needs to their business operations. The results are presented in Table 4.

The top three most significant business information needs were: 'how to nurture growth of SBEs' (selected by $201(67.9 \%)$ SBE respondents); information on 'how to manage cash flows in a business', (201: 67.9\%); and information on 'how to effectively manage a business venture' (192: $64.9 \%$ ). The three least significant business information needs were: 'regulations, standards and other legislations requirements for SBEs' (127: $42.9 \%$ ); 'how to write a good business plan' (126: $42.6 \%$ ); and information on 'available institutional support and county government intervention programmes and services that are of assistance to SBEs (110: $37.2 \%)$.

\section{Business information queries received at public libraries from SBEs in Meru County}

Although SBEs identified a wide range of business information needs, it was clear that they rarely sought to fulfil these needs from public libraries. The staff of the public libraries in Meru County were asked to indicate, on a 5-point Likert scale (ranging from $5=$ very often sought to $1=$ never sought), how often they were receiving queries based on the business information needs identified by SBEs. Their responses are summarized in Table 5 .

In comparing the business information needs identified in Table 4 with the business information queries received at public libraries shown in Table 5 , it is clear that, both overall and in relation to specific business information needs, the number of queries 'sought very often and often' at the public libraries is very low compared with the number of significant information needs identified by the SBEs. Of the top three business information needs identified in Table 4, only one, 'how to effectively manage a small business venture', appeared among the top three most sought queries in Table 5. This ranked equal first among the queries with 'information about financing a small business venture', but the latter only ranked sixth among the business information needs. The two rankings agreed, however, on ranking 'regulations, standards and other legislations requirements for SBEs' last in importance. These results show that public libraries were not commonly being consulted by SBEs for business information needs in Meru County. 
Table 2. Profile of small-scale business enterprises $(\mathrm{N}=296)$.

\begin{tabular}{|c|c|c|}
\hline Profile attributes & Number of respondents & Percentage \\
\hline \multicolumn{3}{|l|}{ Trading area } \\
\hline Makutano/Meru & 94 & 31.8 \\
\hline Nkubu & 77 & 26.0 \\
\hline Maua/Kangeta & 55 & 18.6 \\
\hline Kianjai & 37 & 12.5 \\
\hline Timau & 33 & II.I \\
\hline \multicolumn{3}{|l|}{ Gender } \\
\hline Female & 166 & 56.1 \\
\hline Male & 130 & 43.9 \\
\hline \multicolumn{3}{|l|}{ Highest level of education completed } \\
\hline Primary school certificate & 16 & 5.4 \\
\hline O-level or A-level certificate & 90 & 30.4 \\
\hline College certificate & 89 & 30.1 \\
\hline College diploma & 62 & 20.9 \\
\hline Bachelor degree from university & 23 & 7.8 \\
\hline Postgraduate degree (Masters or $\mathrm{PhD}$ ) from university & 16 & 5.4 \\
\hline \multicolumn{3}{|l|}{ Age bracket } \\
\hline Between 20 and 30 years & 80 & 27.0 \\
\hline Between 31 and 40 years & 101 & 34.1 \\
\hline Between $4 \mathrm{I}$ and 50 years & 99 & 33.4 \\
\hline Between $5 \mathrm{I}$ and 60 years & 12 & 4.1 \\
\hline From $6 \mathrm{I}$ years and above & 4 & 1.4 \\
\hline \multicolumn{3}{|l|}{ How long the business has been in operation } \\
\hline $0-1$ year & 41 & 13.9 \\
\hline $2-4$ years & 86 & 29.1 \\
\hline $5-6$ years & 109 & 36.8 \\
\hline $7-10$ years & 22 & 7.4 \\
\hline More than 10 years & 38 & 12.8 \\
\hline \multicolumn{3}{|l|}{ Form of business ownership } \\
\hline I am a sole proprietor (I own the business alone) & 268 & 90.5 \\
\hline The business is jointly owned with other business partners & 28 & 9.5 \\
\hline \multicolumn{3}{|l|}{ Number of employees employed in the business } \\
\hline Zero employees & $|5|$ & 51.0 \\
\hline I have I employee & 79 & 26.7 \\
\hline I have 2 employees & 38 & 12.8 \\
\hline I have between 3 to 5 employees & 23 & 7.8 \\
\hline I have between II to 20 employees & 5 & 1.7 \\
\hline \multicolumn{3}{|c|}{ Range of amount used to start the current business (in Kenya shillings) } \\
\hline $3000-5,000$ & 50 & 16.9 \\
\hline $6,000-10,000$ & 50 & 16.9 \\
\hline $11,000-20,000$ & 42 & 14.2 \\
\hline $21,000-50,000$ & 51 & 17.2 \\
\hline $51,000-100,000$ & 26 & 8.8 \\
\hline $101,000-200,000$ & 52 & 17.6 \\
\hline
\end{tabular}

Range of income per month - the average range of income earned after paying rent and bills from SBE every month (in Kenya shillings)

$$
\begin{aligned}
& 1,000-3,000 \\
& 3,100-5,000 \\
& 5,100-10,000 \\
& 11,000-20,000 \\
& 21,000-30,000 \\
& 31,000-50,000 \\
& 51,000-75,000 \\
& 76,000-100,000
\end{aligned}
$$


Table 3. Profile of staff who work at public libraries in Meru County $(\mathrm{N}=20)$.

\begin{tabular}{|c|c|c|}
\hline Profile attributes for library staff & $\begin{array}{l}\text { Number of } \\
\text { respondents }\end{array}$ & Percentage \\
\hline \multicolumn{3}{|l|}{ Name of the library } \\
\hline Meru District Library & 9 & 45.0 \\
\hline $\begin{array}{l}\text { Timau Community } \\
\text { Library }\end{array}$ & 6 & 30.0 \\
\hline $\begin{array}{l}\text { Mikumbune Community } \\
\text { Library }\end{array}$ & 5 & 25.0 \\
\hline \multicolumn{3}{|l|}{ Gender } \\
\hline Male & 12 & 60.0 \\
\hline Female & 8 & 40.0 \\
\hline \multicolumn{3}{|l|}{ Current position in the library } \\
\hline Assistant librarian & 8 & 40.0 \\
\hline Library assistant & 4 & 20.0 \\
\hline $\begin{array}{l}\text { Librarian in-charge of the } \\
\text { library }\end{array}$ & 3 & 15.0 \\
\hline Library attendant/clerk & 3 & 15.0 \\
\hline Senior library assistant & 2 & 10.0 \\
\hline \multicolumn{3}{|c|}{ The highest completed level of education } \\
\hline $\begin{array}{l}\text { College diploma in library } \\
\text { studies/science }\end{array}$ & 10 & 50.0 \\
\hline $\begin{array}{l}\text { College certificate in } \\
\text { library studies/science }\end{array}$ & 5 & 25.0 \\
\hline $\begin{array}{l}\text { O-level or A-level } \\
\text { certificate }\end{array}$ & 3 & 15.0 \\
\hline $\begin{array}{l}\text { Bachelor degree from } \\
\text { university in library } \\
\text { studies/science }\end{array}$ & 1 & 5.0 \\
\hline $\begin{array}{l}\text { Postgraduate degree } \\
\text { (Master's or PhD) }\end{array}$ & 1 & 5.0 \\
\hline \multicolumn{3}{|c|}{ Years of work experience in the library } \\
\hline Between I and 2 years & 3 & 15.0 \\
\hline Between 3 and 7 years & 3 & 15.0 \\
\hline Between II and I5 years & 5 & 25.0 \\
\hline From 16 years and above & 9 & 45.0 \\
\hline
\end{tabular}

\section{Level of SBEs' awareness of places/providers of business information in Meru County}

SBE respondents were asked to indicate their level of awareness of 17 specific places/providers of business information. More than half the respondents said they were 'very much aware' of suppliers (168: 56.8\%), fellow business men/women (158: 53.4\%) and customers (151: $51.0 \%$ ) as providers of business information, while more than one third were aware of the Internet (131: 44.3\%), social media groups (122: $41.2 \%)$ and college or university business libraries (121: 40.95) as information providers. Public/community libraries were identified by 89 respondents
(30.1\%) as information providers of which they were 'very much aware', despite the low use made of public libraries as sources of business information which may be reflected in the fact that one third (100: $33.8 \%$ ) of respondents said they were not aware of public libraries in this context. The institutions of which the biggest numbers of respondents were not aware were the Department of Trade and Enterprise Development under the county government (165: $55.7 \%$ ), the District Documentation and Information Services (160: $54.1 \%$ ) and the National Bureau of Statistics (174: 58.8\%).

\section{SBEs' usage and satisfaction level of the places/ providers of business information}

The study sought to ascertain the frequency of use of the various places that were providing business information, and the level of satisfaction to SBEs who had used any of them. In terms of total usage of business information providers, the results in Table 7 closely follow the levels of awareness reported in Table 6, with the same providers - suppliers (236: 79.7\%), fellow business men/women (240: 81.1\%) customers (229: $77.4 \%$ ), the Internet (198: $66.9 \%$ ), and social media groups (217: $73.3 \%$ ) - occupying the top five places, though not in the same order.

The least consulted information provider was the Department of Trade and Enterprise Development under the county government (41: 13.9\%). This may be attributed to the low level of awareness of this source as confirmed by the results in Table 6 . Both these results are somewhat surprising as this department is responsible for nurturing the growth of the small business sector.

The last column of Table 7 shows the numbers of satisfied users of each type of provider expressed as percentages of the total number of users in each case. While the top five most commonly consulted business information providers also show high numbers of satisfied users, the percentages of satisfied users were lower than those recorded for some other categories. The highest level of satisfaction was recorded in respect of bookshops ( $87.2 \%)$, followed by the Internet $(86.4 \%)$ and, perhaps surprisingly, public/community libraries $(83.1 \%)$.

Most of the 118 SBEs (85: $72.0 \%$ ) who were consulting public libraries were using them once a month, $20(16.9 \%)$ were using them once a week, and 13 $(11.0 \%)$ were using them on daily basis, while 178 $(60.1 \%)$ had never used them. It is clear that those 
Table 4. Business information needs $(\mathrm{N}=296)$.

\begin{tabular}{|c|c|c|c|}
\hline The information needed in business operations & $\begin{array}{l}\text { Significant } \\
\text { n (\%) }\end{array}$ & $\begin{array}{c}\text { Moderately } \\
\text { Significant } \mathrm{n}(\%)\end{array}$ & $\begin{array}{l}\text { Not significant } \\
n(\%)\end{array}$ \\
\hline Information on how to nurture growth of SBEs & $201(67.9)$ & $53(17.9)$ & $42(14.2)$ \\
\hline Information on how to manage cash flows in SBEs & $201(67.9)$ & $58(19.6)$ & $37(12.5)$ \\
\hline Information on how to effectively manage a small business venture & $192(64.9)$ & $79(26.7)$ & $25(8.4)$ \\
\hline How to identify business opportunities & $191(64.5)$ & $83(28.0)$ & $22(7.4)$ \\
\hline $\begin{array}{l}\text { The kind of business information sources and services available for my } \\
\text { business and where to get them }\end{array}$ & $18 \mid(6||)$. & $83(28.0)$ & $32(10.8)$ \\
\hline Information about financing a small business venture & $168(56.8)$ & $89(30.1)$ & $39(13.2)$ \\
\hline Information on how to market products and services of my business & $168(56.8)$ & $83(28.0)$ & $45(15.2)$ \\
\hline Information on how to diversify investment ventures & $147(49.7)$ & $104(35.1)$ & $45(15.2)$ \\
\hline $\begin{array}{l}\text { Information on training opportunities available in my county to add } \\
\text { business skills }\end{array}$ & I4I (47.6) & $71(24.0)$ & $84(28.4)$ \\
\hline Information on how to minimize/mitigate risks and disasters in SBEs & $140(47.3)$ & $97(32.8)$ & $59(19.9)$ \\
\hline Information on how to conduct & $137(46.3)$ & $87(29.4)$ & $72(24.3)$ \\
\hline $\begin{array}{l}\text { The information about equipment, facilities and technology needed in my } \\
\text { business }\end{array}$ & $133(44.9)$ & $106(35.8)$ & $57(19.3)$ \\
\hline $\begin{array}{l}\text { Information on relevant networks and collaboration opportunities that can } \\
\text { help to boost my business }\end{array}$ & $129(43.6)$ & $113(38.2)$ & $54(18.2)$ \\
\hline Regulations, standards and other legislations requirements for SBEs & $127(42.9)$ & 115( & $54(18.2)$ \\
\hline How to write a good business plan & $126(42.6)$ & $99(33.4)$ & $71(24.0)$ \\
\hline $\begin{array}{l}\text { Information on available institutional support and county government } \\
\text { intervention programmes and services that are of assistance to SBEs. }\end{array}$ & $110(37.2)$ & $57(19.3)$ & $129(43.6)$ \\
\hline
\end{tabular}

Table 5. Business information queries received at public libraries from SBEs in Meru County $(N=20)$.

\begin{tabular}{|c|c|c|c|}
\hline $\begin{array}{l}\text { Queries received at public libraries on business information needs of } \\
\text { SBEs }\end{array}$ & $\begin{array}{c}\text { Sought } \\
\text { (very often } \\
\text { and often) } \\
\mathrm{n}(\%)\end{array}$ & $\begin{array}{c}\text { Not sought } \\
\text { (very rare and rare) } \\
\mathrm{n}(\%)\end{array}$ & $\begin{array}{l}\text { Never sought } \\
\mathrm{n}(\%)\end{array}$ \\
\hline Information about financing a small business venture & $9(45.0 \%)$ & $4(20.0 \%)$ & $7(35.0 \%)$ \\
\hline Information on how to effectively manage a small business venture & $9(45.0 \%)$ & $4(20.0 \%)$ & 7 (35.0\%) \\
\hline How to identify business opportunities & $8(40.0 \%)$ & $5(25.0 \%)$ & 7 (35.0\%) \\
\hline How to write a good business plan & $7(35.0 \%)$ & $5(25.0 \%$ & $8(30.0 \%)$ \\
\hline Information on how to nurture growth of SBEs & $7(35.0 \%)$ & $6(30.0 \%)$ & $7(35.0 \%)$ \\
\hline $\begin{array}{l}\text { The information about equipment, facilities and technology needed in a } \\
\text { particular business }\end{array}$ & $6(30.0 \%)$ & $7(35.0 \%)$ & $7(35.0 \%)$ \\
\hline Regulations, standards and other legislations requirements for SBEs & $6(30.0 \%)$ & $2(10.0 \%)$ & $12(60.0 \%)$ \\
\hline Information on how to manage cash flows in SBEs & $6(30.0 \%)$ & $3(15.0 \%)$ & II (55.0\%) \\
\hline Information on how to market products and services & $5(25.0 \%)$ & $2(10.0 \%)$ & $13(65.0 \%)$ \\
\hline $\begin{array}{l}\text { Information on available training opportunities to improve one's } \\
\text { business skills }\end{array}$ & $5(25.0 \%)$ & $8(40.0 \%)$ & $7(35.0 \%)$ \\
\hline $\begin{array}{l}\text { The kind of business information sources and services available for } \\
\text { business and where to get them }\end{array}$ & $5(25.0 \%)$ & $8(40.0 \%)$ & $7(35.0 \%)$ \\
\hline Information on how to minimize/mitigate risks in SBEs & $5(25.0 \%)$ & $7(35.0 \%)$ & $8(40.0 \%)$ \\
\hline Information on how to diversify investment ventures & $5(25.0 \%)$ & $8(40.0 \%)$ & 7 (35.0\%) \\
\hline Information on relevant networks and collaboration opportunities & $3(\mid 5.0 \%)$ & $9(45.0 \%)$ & $8(40.0 \%)$ \\
\hline $\begin{array}{l}\text { Information on available institutional support and county government } \\
\text { intervention programs and services applicable to SBEs }\end{array}$ & I (5.0\%) & II (55.0\%) & $8(40.0 \%)$ \\
\hline
\end{tabular}


Table 6. Level of awareness of places/providers of business information $(N=296)$.

\begin{tabular}{lcrc}
\hline & \multicolumn{3}{c}{ Very much aware } \\
Places/providers of business information & $\mathrm{n}(\%)$ & $\mathrm{n}(\%)$ & $\mathrm{n}(\%)$ \\
\hline From suppliers & $168(56.8)$ & $68(23.0)$ & $60(20.3)$ \\
Fellow businessmen/women & $158(53.4)$ & $68(23.0)$ & $70(23.6)$ \\
From customers & $151(51.0)$ & $86(29.1)$ & $59(19.9)$ \\
Internet & $131(44.3)$ & $78(26.4)$ & $87(29.4)$ \\
Social media groups such as Facebook, Instagram, WhatsApp & $122(41.2)$ & $97(32.8)$ & $77(26.0)$ \\
College or university business libraries & $121(40.9)$ & $84(28.4)$ & $91(30.7)$ \\
Church & $94(31.8)$ & $86(29.1)$ & $116(39.2)$ \\
Public library/community library & $89(30.1)$ & $107(36.1)$ & $100(33.8)$ \\
Commercial business information centres & $75(25.3)$ & $74(25.0)$ & $147(49.7)$ \\
Bookshops & $74(25.0)$ & $109(36.8)$ & $113(38.2)$ \\
Municipal council offices & $71(24.0)$ & $95(32.1)$ & $130(43.9)$ \\
Non-government organisations (NGOs) & $54(18.2)$ & $99(33.4)$ & $143(48.3)$ \\
National archives & $43(14.5)$ & $72(24.3)$ & $181(61.1)$ \\
Other libraries apart from public/community libraries & $38(12.8)$ & $88(29.7)$ & $170(57.4)$ \\
Department of Trade and Enterprise Development under the county & $29(9.8)$ & $102(34.5)$ & $165(55.7)$ \\
$\quad$ government & & & \\
District Documentation and Information Services & $28(9.5)$ & $108(36.5)$ & $160(54.1)$ \\
National Bureau of Statistics & $20(6.8)$ & $102(34.5)$ & $174(58.8)$ \\
\hline
\end{tabular}

SBEs who had used public libraries indicated high satisfaction, though the low numbers of business information queries received in the public libraries (Table 5) suggest that most SBE users were not submitting formal business information requests, but probably using the libraries independently or for other purposes, as shown in Table 8.

\section{Purposes and/or reasons for SBEs' visitation to the public libraries}

Table 8 shows that three quarters of SBE respondents (224: $75.7 \%$ ) said they used the public library to obtain information on health matters. Obtaining information on business matters ranked only second in importance, with 209 responses (70.6\%), equally with helping children do homework (209: 70.6\%). Respondents said they used public libraries for several other purposes, among which the lowest scores were assigned to social enjoyment, 49 (16.6\%), to meet people and friends, 37 (12.5\%), to hold meetings, 37 $(12.5 \%)$, and for leisure and entertainment, 36 $(12.2 \%)$. It should be noted that there is a considerable discrepancy between the number of respondents shown in Table 7 as having used public libraries for business information (118:39.9\%) and those shown in Table 8 as having used them for the same purpose (209: 70.6\%). This discrepancy will need to be investigated further in subsequent research.
The responses from five SBEs who responded to the open-ended questions on the services they were expecting from public libraries indicated preferences for the provision of Internet services, business information materials, financial management services for SBEs, and services on writing a business plan.

Measures needed at public /community libraries to support the development of SBEs in Meru County

The questionnaires for both SBEs and library staff included a list of 15 possible measures needed at public libraries to support the development of SBEs. Respondents were asked to indicate if they considered each suggested measure to be 'significant', or 'major'; moderately significant' or 'minor'; or 'not significant' or 'not major at all'. The responses from both groups are presented in Table 9.

Table 9 reveals that all 15 measures were regarded as 'significant' by more than half the SBEs and 'major' by the majority of library staff. The two groups agreed on the three most important measures:

1. The business librarians to coach, mentor and train business people on how to use Internet sources for information about businesses,

2. Equip public library with current business information materials (both print and via Internet). 
Table 7. SBEs' usage and satisfaction level of places/providers of business information ( $N=296)$.

\begin{tabular}{|c|c|c|c|c|c|c|}
\hline $\begin{array}{l}\text { Providers/places where one can } \\
\text { obtain business information }\end{array}$ & $\begin{array}{l}\text { Once a } \\
\text { month } \\
\mathrm{n}(\%)\end{array}$ & $\begin{array}{l}\text { Once a } \\
\text { week } \\
\text { n (\%) }\end{array}$ & $\begin{array}{l}\text { Daily } \\
\text { n (\%) }\end{array}$ & $\begin{array}{c}\text { Total of } \\
\text { SBEs who } \\
\text { had used } \\
\text { n (\%) }\end{array}$ & $\begin{array}{l}\text { Never } \\
\text { used it } \\
\mathrm{n}(\%)\end{array}$ & $\begin{array}{c}\text { Satisfaction level of } \\
\text { users (very satisfied } \\
\text { and satisfied)* } \\
\mathrm{n}(\%)\end{array}$ \\
\hline & I & 2 & 3 & 4 & 5 & 6 \\
\hline Fellow businessmen/women & $73(30.4)$ & $5 \mid(2 \mid .3)$ & I I $6(48.3)$ & $240(8 I . I)$ & $56(18.9)$ & $165(68.8)$ \\
\hline From suppliers & $54(22.9)$ & $70(29.7)$ & II $2(47.5)$ & $236(79.7)$ & $60(20.3)$ & $180(76.3)$ \\
\hline From customers & $66(28.8)$ & $31(13.5)$ & $132(57.6)$ & $229(77.4)$ & $67(22.6)$ & 179 (78.2) \\
\hline $\begin{array}{l}\text { Social media groups such in } \\
\text { Facebook, Instagram, WhatsApp }\end{array}$ & $41(18.9)$ & $38(17.5)$ & $138(63.6)$ & $217(73.3)$ & $79(26.7)$ & I7I (78.8) \\
\hline Internet & $52(26.3)$ & $42(21.2)$ & $104(52.5)$ & $198(66.9)$ & $98(33.1)$ & I7I (86.4) \\
\hline Church & $52(32.3)$ & $105(65.2)$ & $4(2.5)$ & $161(54.4)$ & $135(45.6)$ & II 4 (70.8) \\
\hline Public library/ community library & $85(72.0)$ & $20(16.9)$ & $13(1 \mid .0)$ & $118(39.9)$ & $178(60.1)$ & $98(83.1)$ \\
\hline Bookshops & $35(29.9)$ & $32(27.4)$ & $50(42.7)$ & $117(39.5)$ & $179(60.5)$ & $102(87.2)$ \\
\hline Municipal council offices & $85(81.0)$ & $15(14.3)$ & $5(4.8)$ & $105(35.5)$ & $191(64.5)$ & $69(65.7)$ \\
\hline $\begin{array}{l}\text { Commercial business information } \\
\text { centres }\end{array}$ & $16(21.3)$ & 14 (18.7) & $45(60.0)$ & $75(25.3)$ & $221(74.7)$ & $43(57.3)$ \\
\hline $\begin{array}{l}\text { Other libraries apart from public/ } \\
\text { community libraries }\end{array}$ & $57(87.7)$ & $4(6.2)$ & $4(6.2)$ & $65(22.0)$ & $231(78.0)$ & $46(70.8)$ \\
\hline $\begin{array}{l}\text { District Documentation and } \\
\text { Information Services }\end{array}$ & $5 I(8 I .0)$ & $4(6.3)$ & $8(12.7)$ & $63(21.3)$ & $233(78.7)$ & $49(77.8)$ \\
\hline $\begin{array}{l}\text { Non-government organisations } \\
\text { (NGOs) }\end{array}$ & $50(80.6$ & $12(19.4)$ & 0 & $62(20.9)$ & $234(79.1)$ & $43(69.4)$ \\
\hline National archives & $17(30.9)$ & $6(10.9)$ & $32(58.2)$ & $55(18.6)$ & $24 I(8 I .4)$ & $32(58.2)$ \\
\hline National Bureau of Statistics & $30(55.6)$ & $16(29.6)$ & $8(14.8)$ & $54(18.2)$ & $242(81.8)$ & $26(48.1)$ \\
\hline $\begin{array}{l}\text { College or university business } \\
\text { libraries }\end{array}$ & $28(59.6)$ & $8(17.0)$ & II (23.4) & 47 (I5.9) & $249(84.1)$ & $30(63.8)$ \\
\hline $\begin{array}{l}\text { Department of Trade and } \\
\text { Enterprise Development under } \\
\text { the county government }\end{array}$ & $2 \mid(5 \mid .2)$ & $4(9.8)$ & $16(39.0)$ & $4 \mid(13.9)$ & $255(86.1)$ & $15(36.6)$ \\
\hline
\end{tabular}

* Percentages shown in column 6 (satisfaction level) relate to total numbers of users of each type of provider shown in column 4

3. Establishment of business corners where all information materials related to businesses are kept and related information service is offered for free.

4. The library staff also considered "Ensure a dedicated librarian who has business background to address information needs of the business people" to be of equal importance.

\section{Suggestions to improve the public libraries' service delivery to SBEs}

SBEs were finally asked to state in their own words what they thought should be done at public/community libraries for them to provide effective business information services to support the development of SBEs in Meru County. Sixty (20.3\%) SBEs responded to this open-ended question and their comments were thematically analyzed and summarized in 13 statements. The suggestions given emphasized the need to build collections in business information, to develop the training and advisory role of public libraries, information packaging for business clients, creating more awareness, organizing events and forums for capacity building, and the need for library staff to be knowledgeable in business matters.

\section{Discussions}

The majority of SBEs in Meru County possess basic numeracy and literacy skills, which agrees with the findings of Mbugua, Wangoi, Ogada and Kariuki (2013:289) in Kenya, and Erastus, Stephen and Abdullai (2014:34) in Ghana - all of which show that business people are not necessarily illiterate. The ages 
Table 8. SBEs' purposes for visiting a public/community library $(N=296)$.

\begin{tabular}{|c|c|c|c|c|}
\hline \multirow[b]{2}{*}{ Suggested purpose / reasons } & \multicolumn{2}{|l|}{ Yes } & \multicolumn{2}{|l|}{ No } \\
\hline & $\begin{array}{c}\text { No. of } \\
\text { respondents (n) }\end{array}$ & (\%) & $\begin{array}{c}\text { No. of } \\
\text { respondents (n) }\end{array}$ & $(\%)$ \\
\hline To obtain information on health issues & 224 & 75.7 & 72 & 24.3 \\
\hline To obtain information on business matters & 209 & 70.6 & 87 & 29.4 \\
\hline To help children do homework & 209 & 70.6 & 87 & 29.4 \\
\hline For educational purposes (for homework or reading for exams) & 208 & 70.3 & 88 & 29.7 \\
\hline To conduct a job search or write a cv & 194 & 65.5 & 102 & 34.5 \\
\hline To obtain information on online government services & 181 & 61.1 & 115 & 38.9 \\
\hline To obtain information on agriculture & 176 & 59.5 & 120 & 40.5 \\
\hline Just to read - reading services & 162 & 54.7 & 134 & 45.3 \\
\hline To look for information on starting or running a business & 149 & 50.3 & 147 & 49.7 \\
\hline Local news/information & 145 & 49.0 & $|5|$ & 51.0 \\
\hline To surf the internet & 125 & 42.2 & 171 & 57.8 \\
\hline International or national news /information & 110 & 37.2 & 186 & 62.8 \\
\hline To relax and rejuvenate the mind & 104 & 35.1 & 192 & 64.9 \\
\hline It is a safe place for my child to spend time & 91 & 30.7 & 205 & 69.3 \\
\hline To type my work & 90 & 30.4 & 206 & 69.6 \\
\hline To obtain information on politics & 88 & 29.7 & 208 & 70.3 \\
\hline To communicate with distant friends or relatives & 53 & 17.9 & 243 & 82.1 \\
\hline Social enjoyment & 49 & 16.6 & 247 & 83.4 \\
\hline To meet people and friends & 37 & 12.5 & 259 & 87.5 \\
\hline To hold meetings & 37 & 12.5 & 259 & 87.5 \\
\hline Leisure and entertainment & 36 & 12.2 & 260 & 87.8 \\
\hline
\end{tabular}

of most SBEs in Meru fall within their productive years, so the need for any supportive initiatives is paramount. The lack of background training in business matters among SBEs reveals capacity building opportunities for stakeholders such as public libraries. The majority of staff working at public libraries in Meru County are technically qualified and have requisite experience. This competence is critical in the provision of information services. They are, however, inadequate in the effective execution of library strategy (Telstra Corporation Limited 2004; Wilson 2013).

Proper understanding of the information needs that are specific to the SBE sector is an important prerequisite to an effective business information service. In this study, the most significant business information needs were more generic, with slight variations among the different industries. Similar to the observations by Vuori (2006), the scope of the business information needs outlined in Tables 4 and 5 comprises both nonfinancial and financial information, and covers all the stages of business development as outlined by Bwisa (2011:100), and Kuratko and Hodgetts (2004:548). The results agree with other previous studies such as by Kamunge, Njeru and Tirimba (2014), Karadag
(2015), Garcia-Alsina, Ortoll and Cobarsí-Morales (2011). Bouthillier's study of 2003 was more comprehensive and equally comparable. Chiware (2007), Okello-Obura et al. (2007) and Feldmann (2014) linked high small business failure to the lack of relevant and credible business information at each stage of business development. Consequently, public libraries are better placed to configure objective business information solutions for supporting specific SBEs sector throughout all the stages of business growth.

However, the low level of awareness of the public library as a place for business information currently limits the library's effectiveness as a source of such information. The preferred places for business information among SBEs in Meru County were largely informal, that is, suppliers, fellow businessmen/ women, customers, the Internet and social media groups such as Facebook, Instagram, WhatsApp and the church. Concerns as to the practice among SBEs of consulting informal sources of information had also been raised by Bouthillier (2003:126). The low ranking of the public library as a preferred place for business information in this study confirms the finding by Okello-Obura et al. (2007:136) who reported public 
Table 9. Measures needed at public /community libraries in order to support the information needs of SBEs in Meru County.

\begin{tabular}{|c|c|c|c|c|c|c|}
\hline \multirow[b]{2}{*}{ Suggested measures } & \multicolumn{3}{|c|}{$\begin{array}{l}\text { Responses from SBEs } \\
\qquad(N=296)\end{array}$} & \multicolumn{3}{|c|}{$\begin{array}{l}\text { Responses from public library staff } \\
\qquad(\mathrm{N}=20)\end{array}$} \\
\hline & $\begin{array}{l}\text { Significant } \\
\text { n (\%) }\end{array}$ & $\begin{array}{l}\text { Moderately } \\
\text { Significant } \\
\text { n (\%) }\end{array}$ & $\begin{array}{l}\text { Not } \\
\text { significant } \\
\text { n (\%) }\end{array}$ & $\begin{array}{l}\text { Major } \\
\mathrm{n}(\%)\end{array}$ & $\begin{array}{l}\text { Not major } \\
\text { (Minor } \\
\mathrm{n}(\%)\end{array}$ & $\begin{array}{l}\text { Not major } \\
\text { at all } \\
\mathrm{n}(\%)\end{array}$ \\
\hline $\begin{array}{l}\text { The business librarians to coach, mentor and } \\
\text { train business people on how to use Internet } \\
\text { sources for information about businesses }\end{array}$ & $215(72.6)$ & $65(22.0)$ & $16(5.4)$ & $20(100.0)$ & 0 & 0 \\
\hline $\begin{array}{l}\text { Equip public library with current business } \\
\text { information materials (both print and via } \\
\text { internet) }\end{array}$ & $213(72.0)$ & $67(22.6)$ & $16(5.4)$ & $19(95.0)$ & I (5.0) & 0 \\
\hline $\begin{array}{l}\text { Establishment of business corners where all } \\
\text { information materials related to businesses } \\
\text { are kept and related information service is } \\
\text { offered for free }\end{array}$ & $206(69.6)$ & 7I (24) & $19(6.4)$ & $19(95.0)$ & I (5.0) & 0 \\
\hline $\begin{array}{l}\text { Library to conduct/coordinate/organize for } \\
\text { periodic business trainings, workshop and } \\
\text { seminars that are specific to particular types } \\
\text { of business people }\end{array}$ & $194(65.5)$ & $61(20.6)$ & $4 \mid(13.9)$ & $17(85.0)$ & $2(10.0)$ & I (5) \\
\hline $\begin{array}{l}\text { Provide computers/iPads/tablets that are } \\
\text { connected to the Internet for business } \\
\text { people to use at public/community libraries }\end{array}$ & $192(64.9)$ & $69(23.3)$ & 35 (II.8) & $17(85.0)$ & $2(10.0)$ & I (5.0) \\
\hline $\begin{array}{l}\text { Public libraries to offer business consultancy, } \\
\text { reference and referral services to SBEs }\end{array}$ & $186(62.8)$ & $85(28.7)$ & $25(8.4)$ & $17(85.0)$ & $3(I 5.0)$ & 0 \\
\hline $\begin{array}{l}\text { Open more community libraries in local areas } \\
\text { where business people can access them with } \\
\text { ease and without traveling long distances }\end{array}$ & $186(62.8)$ & $69(23.3)$ & $4 \mid(13.9)$ & $14(70.0)$ & $6(30.0)$ & 0 \\
\hline $\begin{array}{l}\text { Public libraries to be carrying out market } \\
\text { research and provide market intelligence } \\
\text { information services to SBEs }\end{array}$ & $175(59.1)$ & $79(26.7)$ & $42(14.2)$ & $17(85.0)$ & $3(15.0)$ & 0 \\
\hline $\begin{array}{l}\text { Ensure a dedicated librarian who has business } \\
\text { background to address information needs of } \\
\text { the SBEs }\end{array}$ & $169(57.1)$ & $92(31.1)$ & 35 (II.8) & $19(95.0)$ & 0 & I (5.0) \\
\hline $\begin{array}{l}\text { Public libraries to allocate sufficient funding for } \\
\text { supporting the provision of business } \\
\text { information sources, services and } \\
\text { programmes to local business people }\end{array}$ & $166(56.1)$ & $87(29.4)$ & $43(14.5)$ & $14(70.0)$ & $5(25.0)$ & I (5.0) \\
\hline $\begin{array}{l}\text { Public libraries to network and collaborate } \\
\text { with research organizations and local } \\
\text { university business schools for dissemination } \\
\text { of business research information and } \\
\text { advisory services to local business people }\end{array}$ & $163(55.1)$ & $98(33.1)$ & 35 (II.8) & $17(85.0)$ & $3(15.0)$ & 0 \\
\hline $\begin{array}{l}\text { Library to organize business competition } \\
\text { events to promote business information } \\
\text { services to SBEs }\end{array}$ & $161(54.4)$ & $96(32.4)$ & $39(13.2)$ & I $5(75.0)$ & $5(25.0)$ & 0 \\
\hline $\begin{array}{l}\text { Library to set up a meeting room where } \\
\text { business partners can meet to discuss } \\
\text { business matters without being charged }\end{array}$ & $159(53.7)$ & $86(29.1)$ & $5 I(17.2)$ & $16(80.0)$ & I (5.0) & $3(15.0)$ \\
\hline
\end{tabular}


Table 9. (continued)

\begin{tabular}{|c|c|c|c|c|c|c|}
\hline \multirow[b]{2}{*}{ Suggested measures } & \multicolumn{3}{|c|}{$\begin{array}{l}\text { Responses from SBEs } \\
\qquad(N=296)\end{array}$} & \multicolumn{3}{|c|}{$\begin{array}{l}\text { Responses from public library staff } \\
\qquad(\mathrm{N}=20)\end{array}$} \\
\hline & $\begin{array}{l}\text { Significant } \\
\text { n (\%) }\end{array}$ & $\begin{array}{l}\text { Moderately } \\
\text { Significant } \\
\text { n (\%) }\end{array}$ & $\begin{array}{l}\text { Not } \\
\text { significant } \\
\mathrm{n}(\%)\end{array}$ & $\begin{array}{l}\text { Major } \\
\mathrm{n}(\%)\end{array}$ & $\begin{array}{l}\text { Not major } \\
\text { (Minor } \\
\mathrm{n}(\%)\end{array}$ & $\begin{array}{l}\text { Not major } \\
\text { at all } \\
\mathrm{n}(\%)\end{array}$ \\
\hline $\begin{array}{l}\text { Libraries to conduct annual assessment to } \\
\text { evaluate the impacts of their business } \\
\text { information sources and services on the } \\
\text { business people }\end{array}$ & $159(53.7)$ & 91 (30.7) & $46(15.5)$ & $12(60.0)$ & $5(25.0)$ & $3(15.0)$ \\
\hline $\begin{array}{l}\text { Ensure interactive and updated public library's } \\
\text { website with a page for local business people }\end{array}$ & 155 (52.4) & $98(33.1)$ & $43(14.5)$ & $16(80.0)$ & $4(20.0)$ & 0 \\
\hline
\end{tabular}

libraries as less reliable and less popular among small and medium enterprises in Northern Uganda. Odini, Otike and Kiplang'at (2012:36) also reported similar observations among the rural women entrepreneurs from Vihiga district in Western Kenya.

In this study, the church as a place for business information appeared to have interested and satisfied 114 SBEs (70.8\%). This reveals the impact of religion in business operations in Africa, where traditional belief systems, and culture, coupled with Western religious dogma, present the church as a trusted source of socio-economic information; hence its significance in influencing business activities (Khan, Alam and Khan, 2005:33; Harmon, Kim and Blake, 2014:243,244). Public libraries should therefore partner and collaborate with the churches in sensitizing communities on the availability and accessibility of business information from local settings.

The low utilization of information from government and its agencies by SBEs was attributed to the lack of awareness, lack of proper systems of disseminating information or unsatisfactory services. Abuya (2011:13, 22-23) identified several barriers to access to information in Kenya, chief of which were prohibitions on the disclosure of information, lack of awareness, and the culture of secrecy in government ministries and departments.

The overall results indicate the great need of positioning the public library as a place for business information. This requires coherent communication of the value of the public library to SBEs (Gichohi, 2014:150), which has implications for key decisions on funding, collection development, staffing and equipment. There are unutilized opportunities for public libraries in Kenya to provide business information sources and services to the SBEs.

\section{Conclusions and recommendations}

The study concludes that SBEs have a myriad of financial and non-financial business information needs which are unique to each business sector/industry, and that cut across all the stages of small business growth. To fulfil these information needs, the majority of SBEs are relying on informal sources and places. Their lack of awareness of the potential of public libraries as sources of business information is no doubt due largely to the fact that the public libraries in Meru County are very few in number and are severely overstretched. More branch libraries should be established, preferably one in each sub-county.

Public libraries should be profiling the SBEs in order to understand their business information needs. This can be realized by inviting SBEs for business seminars and by maintaining reference interview records.

Public libraries should be repositioned as business community development resource centers by providing business information solutions that are not only valuebased but also sector-specific, easy to use and understand; for example, the use of customized information brochures. The study further recommends the need for partnerships and collaboration, outreach activities, business-centric information services, establishment of business resources centers, engagement of sufficient, qualified and experienced staff, and utilization of social media technologies in serving SBEs.

Policies are needed to guide the public library's contribution to business community development, equitable access and dissemination of business information to SBEs regardless of their location and distance. Policies on funding, collection development, staffing, and provision of ICT are also required.

Providing business information solutions to the needs of SBEs from public libraries is a concept that 
is fairly new in Kenya. This study has demonstrated originality by expanding the role of a public library in supporting SBEs, and by revealing value adding activities for public libraries in this endeavour. The findings contribute to the literature in business information and business development in the African context.

\section{Appendix A}

The questionnaires used in this study were extremely detailed and cannot be reproduced here because of their length. Interested readers may obtain copies of the questionnaires from the corresponding author, Paul M Gichohi, Library Department, Kenya Methodist University, Kenya, PO Box 267-60200, Meru, Kenya. Email: pmakuster@gmail.com

The questionnaires and their main sections are as follows:

\section{Questionnaires for small-scale business traders}

Background Information.

Business Information Needs.

Sources consulted and/or places visited for business information.

\section{Questionnaire for public library staff}

Background information.

Library's support to small-scale business enterprises. Business information needs.

\section{References}

Abuya E (2011) Towards promoting access to information in Kenya. Available at: https://spaa.newark.rutgers.edu/ sites/default/files/files/Transparency_Research_Confer ence/Papers/Abuya_Edwin.pdf (accessed 18 March 2016).

African Economic Outlook (2011) Africa and its Emerging Partners. Available at: http://www.afdb.org/fileadmin/ uploads/afdb/Documents/Generic-Documents/Media Embargoed_Content/EN-AEO_2011_embargo\%206 \%20Juin.pdf (accessed 20 June 2014).

Alasadi R and Abdelrahim A (2007) Critical analysis and modelling of small business performance (case study: Syria). Journal of Asia Entrepreneurship and Sustainability 3(2):1-131. Available at: http://www.asiaentre preneurshipjournal.com/AJESIII2Alasadi.pdf (accessed 20 June 2014).

American Library Association (ALA) and Center for Library and Information Innovation (CLII) (2009) $A$ Perfect Storm Brewing: Budget cuts threaten public library services at time of increased demand. University of Maryland. Available at: http://www.ala.org/research/ sites/ala.org.research/files/content/initiatives/plftas/ issuesbriefs/issuebrief_perfectstorm.pdf (accessed 22 December 2015).

Anwar MA and Tuqan A (2006) Information needs and use in the construction materials sector in Kuwait. Electronic Library 24(3): 335-346. DOI: 10.1108/ 02640470610671196.

Bouthillier F (2013) Access to information for small business managers: examination of some strategies and values. Proceedings of the Annual Conference of CAIS/ Actes du congrès annuel de l'ACSI. 0(0). Available at: http://www.cais-acsi.ca/ojs/index.php/cais/article/view/ 14 (accessed 11 June 2015).

Bridge S, O'Neill K and Cromie S (2003) Understanding Enterprise, Entrepreneurship and Small Business, 2nd ed. New York: Palgrave Macmillan.

Bryman A (2012) Social Research Methods, 4th ed. Oxford: Oxford University Press.

Bwisa H (2011) Entrepreneurship Theory and Practice: A Kenyan Perspective. Nairobi: Jomo Kenyatta Foundation.

Cannon E (1999) Library Solution: Cultural and Social Changes. London: Scarecrow.

Chiware ERT (2007) Designing and implementing business information services in the SMME sector in a developing country: the case for Namibia. IFLA Journal 33(2):136-144. DOI: 10.1177/0340035207080308.

Chiware ERT (2008) Business information needs, seeking patterns and information services in the small medium and micro enterprises sector (SMME) in Namibia. Thesis. Available at: http://upetd.up.ac.za/thesis/available/ etd-02052008-171412/ (accessed 18 June 2014).

Cooper R and Schindler PS (2008) Business Research Methods, 10th ed. Boston: McGraw-Hill.

Coy SP, Shipley MF, Omer K and Khan RNA (2007) factors contributory to success: a study of Pakistan's small business owners. Journal of Developmental Entrepreneurship 12(2):181-198.

Creswell JW (2014) Educational Research: Planning, Conducting and Evaluating Quantitative and Qualitative Research, 4th ed. England: Pearson.

Day A (2002) Public business libraries: the next chapter. Business Information Review 19(2):14-20. DOI: 10. 1177/026638202321036196.

Electronic Information for Libraries (2012) Perception Study: EIFL. Available at: http://www.eifl.net/percep tion-study (accessed 24 June 2014).

Erastus YE, Stephen A and Abdullai I (2014) Institutional framework for promoting small and medium scale enterprises in Ghana: perspective of entrepreneurs. Australian Journal of Business and Management Research 3(10). Available at: http://www.ajbmr.com/articlepdf/ aus-29-159i03n10a3.pdf (accessed 11 June 2015).

Feldmann LM (2014) Academic business librarians' assistance to community entrepreneurs. Reference Services Review 42(1):108-128. DOI: 10.1108/RSR-04-20130021. 
Garcia-Alsina M, Ortoll E and Cobarsí-Morales J (2011) Enabler and inhibitor factors influencing competitive intelligence practices. Aslib Proceedings 65(3): 262-288. DOI: 10.1108/00012531311330647.

Gichohi PM (2014) The branding of academic library as a knowledge hub: strategies and success. International Journal for Professional Practice (IJPP) 5(1 \& 2): $140-153$.

Government of Kenya (GOK) (2007) The Constitution of Kenya. Nairobi: Government Printer.

Harmon BE, Kim S H. and Blake CE (2014) Health care information in African-American churches. Journal of Health Care for the Poor and Underserved 25(1): 242-256. DOI: 10.1353/hpu.2014.0047.

Hoyle RH, Harris H and Judd CM (2002) Research Methods in Social Relations, 7th ed. London: Thomson Learning.

Jaworski J (2012) Demand for financial information in small business management. Empirical study. Financial Internet Quarterly 'e-Finanse' 8(3):325-35. Available at: www.e-finanse.com (accessed 15 March 2015).

Jefferson County Public Library (2012) Secret Weapon: How Public Libraries Support Regional Economic Development. Colorado. Available: https://www.goo gle. $\operatorname{com} / \mathrm{search}$ ? sclient $=$ psy-ab\&site $=\&$ source $=$ hp\&q $=$ secret + weapon: + how + public + libraries + support+regional+economic+development\&oq= secret+weapon:3897405.2 (accessed 10 December 2015).

Kadli J and Kumbar BD (2013) Library resources, services and information seeking behavior in changing ICT environment: a literature review. University of NebraskaLincoln Digital Commons. Library Philosophy and Practice (online). Available at: http://digitalcommons. unl.edu/cgi/viewcontent.cgi $?$ article $=2325 \&$ con text=libphilprac (accessed 2 May 2015).

Kamunge MS, Njeru A and Tirimba OI (2014) Factors affecting the performance of small and micro enterprises in Limuru Town Market of Kiambu County, Kenya. International Journal of Scientific and Research Publications 4(12):1-20. Available at: http://www.ijsrp.org/ research-paper-1214/ijsrp-p3618.pdf (accessed 15 March 2015).

Karadag H (2015) Financial management challenges in small and medium-sized enterprises: a strategic management approach. EMAJ: Emerging Markets Journal 5(1): 26-40. DOI: 10.5195/emaj.2015.67.

Kassim MJ (2010) Information needs of Malaysian Bumiputera would-be entrepreneurs. Malaysian Journal of Library and Information Science 15(2):57-69. Available at: http://e-journal.um.edu.my/filebank/published_ article/2802/no.4.pdf (accessed 15 July 2014).

Kenya National Bureau of Statistics (2014) 2014 Economic Survey Report. Available at: http://www.knbs.or.ke/ index.php?option $=$ com_phocadownload\&view $=$ category $\& i d=107 \&$ Itemid $=1181$ (accessed 25 June 2014).

Khan EA, Alam N and Khan SM (2005) Factors affecting the growth of entrepreneurship in small-scale business. Business Review: A Journal of Business Administration Discipline 5(2). Available at: http://works.bepress.com/ cgi/viewcontent.cgi? article $=1004 \&$ context $=$ eijaz khan (accessed 15 July 2014).

Kinnell M, Feather J and Matthews G (1994) Business information provision for small and medium-sized enterprises in China: the application of marketing models. Library Management 15(8):16-23. DOI: 10.1108/ 01435129410071363.

Kuratko DF and Hodgetts RM (2004) Entrepreneurship: Theory, Process and Practice, 6th ed. Australia: Thomson South-Western.

Mbugua JK, Mbugua SN, Wangoi M, Ogada JO and Kariuki JN (2013) Factors affecting the growth of micro and small enterprises: a case of tailoring and dressmaking enterprises in Eldoret. International Journal of Business and Social Science 4(5): 285-293. Available at: http:// ijbssnet.com/journals/Vol_4_No_5_May_2013/34.pdf (accessed 19 June 2014).

Meru County Government (2013) Meru County Integrated Development Plan. Available at: http://meru.go.ke/file/ 20150518_meru_county_integrated_development_ plan_2013_2017.pdf (accessed 15 September 2015).

Meru County Government (2014a) About Meru County Government. Available at: http://meru.go.ke/content. php? $\operatorname{com}=37 \& \operatorname{com} 2=54 \& \operatorname{com} 3=($ accessed 26 June 2014).

Meru County Government (2014b) Department of Trade, Tourism and Cooperative Enterprise Development, Meru County. Available: http://meru.go.ke/department. $\mathrm{php}$ ?com $=2 \& \operatorname{com} 2=10 \& \operatorname{com} 3=51 \& \operatorname{com} 4=($ accessed 26 June 2014).

Migiro S (2005) Small and Medium-scale Manufacturing Enterprises in Kenya: A Perspective on Alternative Sources of Financing. Thesis. University of Zululand. Available at: http://uzspace.uzulu.ac.za/handle/10530/ 1170 (accessed 26 June 2014).

Milam DP (2008) Public Library Strategies for Building Stronger Economies and Communities. Available at: 10. 1002/ncr.219 (accessed 24 December 2015).

Ministry of Devolution and Planning (2013) Meru County Development Profile. Nairobi: Government Printer.

Mugenda AG (2008) Social Science Research: Theory and Principles. Nairobi: Applied Research \& Training Services.

Mutshewa A (2009) A proposed framework for improving the provision of public library service in Botswana. In Information Services and Community Development. Botswana: Botswana Library Association. Available at: http://www.bla.org.bw/images/BLA\%202nd\%20 National\%20Conference.pdf (accessed 19 June). 
Morgan DL (2014) Pragmatism as a paradigm for social research. Qualitative Inquiry (February, 3): 1077800413513733. DOI: 10.1177/1077800413513733.

Online Computer Library Center (OCLC) (2011) How Canadian Public Libraries Stack Up. Available at: http: //www.oclc.org/content/dam/oclc/reports/canadas tackup/214109cef_how_libraries_stack_up.pdf (accessed 19 June 2014).

Odini S, Otike J and Kiplang'at J (2012) Empowering rural women in Kenya to alleviate poverty through provision of information: the case of Vihiga District in Western Province. In Information for Sustainable Development in a Digital Environment Conference, 31-37. Nairobi: Kenya Library Association.

Okello-Obura C (2007) Business information systems design for Uganda's economic development: the case of SMES in Northern Uganda. University of South Africa. Thesis. Available at: http://uir.unisa.ac.za/bitstream/ handle $/ 10500 / 2169 /$ thesis.pdf;jsessionid $=8842 \mathrm{FE} 6820$ 4D4DC60F4629FC2E70BE58? sequence $=1$ (accessed 23 July 2014).

Okello-Obura C, Minishi-Majanja MK, Cloete L and IkojaOdongo JR (2007) Assessment of business information access problems in Uganda. Partnership: the Canadian Journal of Library and Information Practice and Research. 2(2):1-34. Available at: https://journal.lib. uoguelph.ca/index.php/perj/article/viewFile/306/573 (accessed 19 June 2014).

Olabisi SY, Olagbemi AA and Atere AA (2011) Factors Affecting Small-Scale Business Performance in Informal Economy in Lagos State - Nigeria: A Gendered Based Analysis. Available at: http://www.ilo.org/public/eng lish/iira/documents/congresses/regional/lagos2011/ 5thsession/session5a/smallscaleent.pdf (accessed 23 July 2014).

Ong'olo D and Awino S (2013) Small and Medium Enterprises and Devolved Government System: An Assessment of the Regulatory and Institutional Challenges Affecting the SMEs Development in Kenya. (Investment Climate and Business Environment Research Fund). Available at: www.trustafrica.org/icbe (accessed 26 June 2014).

Santos VF D (2009) Public libraries and their contribution towards economic development: a discussion. Library and Information Science Research Electronic Journal 19(2):1-9.

Saunders M, Lewis P and Thornhill A (2009) Research Methods for Business Students, 5th ed. Harlow: Prentice Hall Financial Times.

Smith J (2009) An infinite number of niches a model for delivering information services to small businesses. Business Information Review 26(4):273-278. DOI: 10. 1177/0266382109349614.

Telstra Corporation Limited 2004. How SMEs Access Information on OH\&S and Workers' Compensation.
(Sensis Business Index Special Report). Available at: http://www.safeworkaustralia.gov.au/sites/SWA/about/ Publications/Documents/111/HowSMEsAccessInforma tion_OHS_WorkersCompensation_Sensis_2004_Archi vePDF.pdf (accessed 23 July 2014).

Urwin S (2000) The Internet as an information solution for the small and medium sized business. Business Information Review 17(3):130-137. DOI: 10.1177/ 0266382004237647.

Vuori V (2006) Methods of Defining Business Information Needs. Tampere: Frontiers of e-Business Research. 311-319. Available at: http://www.academia.edu/ 1076006/Methods_of_Defining_Business_Informa tion_Needs (accessed 2 May 2015).

Wilson P (2013) Seven Easy Steps to Supporting Small Business Start Ups and Entrepreneurs in Arizona. Available at: http://jobhelp.azlibrary.gov/pdf/ Seven\%20Easy\%20Steps\%20to\%20Supporting\%20Sm all\%20Business.pdf (accessed 2 May 2015).

Wilson K and Train B (2006) Business information service delivery within a regional context - the role of public libraries. Business Information Review 23(1): 50-57. DOI: $10.1177 / 0266382106063061$.

\section{About the authors}

Paul M. Gichohi holds a PhD in Library and Information Science from the University of South Africa. He has two master's degrees: Master of Library and Information Sciences (MLIS) from Kenyatta University, Kenya, and Master of Business Administration (MBA) from United States International University-Africa (USIU-A), a Bachelor degree in Business Administration from USIU-A, and a Diploma in Information Science of KNEC. He is an experienced academic and business librarian. His research interests are in business librarianship, marketing communication, strategic management, community development and entrepreneurship development. He is currently working at Kenya Methodist University as the acting Deputy University Librarian. Contact: Kenya Methodist University, PO Box 267-60200, Meru, Kenya. Mobile phone: +254721743969. Email: pmakuster@gmail.com

Omwoyo B. Onyancha is a Research Professor at the Department of Information Science, University of South Africa. He holds a PhD in Library and Information Science from the University of Zululand. He holds the National Research Foundation (NRF) C2 rating, which he obtained in 2013. His areas of research include informetrics/ scientometrics/bibliometrics/webometrics/altmetrics, information resource management (IRM), management of information services, knowledge management and organisation, ICTs in LIS education and training, and information 
searching and retrieval (ISR). He has published extensively in the aforementioned areas of research interest. Contact: University of South Africa, PO Box 392, Unisa 0003, South Africa. Tel: 012429 6724. Fax: 012429 3792. Email: onyanob@unisa.ac.za

Frankwell W. Dulle is an employee of the Sokoine University of Agriculture (SUA). He holds a BSc agriculture degree from SUA; a Master's degree in library and information studies of the University of Botswana; and a PhD
(Information Science) of the University of South Africa. His numerous publications and research interest areas are in information and communication technologies' application in education and research; behavioural studies; open access and institutional repositories; information management; and community information services. Contact: Sokoine University of Agriculture, PO Box 3022, Chuo Kikuu, Morogoro, Tanzania. Mobile phone: +255754819531 . E-mail: fwdul le@suanet.ac.tz OR nzengamshe@yahoo.com 